SHORT REPORT

\title{
Health needs of children in prison
}

\author{
J Gould, H Payne
}

Arch Dis Child 2004;89:549-550. doi: 10.1136/adc.2003.029660

At the end of September 2002 there were 2633 children in prison in England and Wales. Since November 2002, the Children Act 1989 applies to children held in prison. The challenge to paediatricians is to recognise and meet the needs of these vulnerable and needy children. This can be achieved by putting in place similar provisions to those recommended for Looked After Children.

A t the end of September 2002, there were 2633 children (those under 18 years of age) held in prison in England and Wales. ${ }^{1}$ Article 37 of The Convention on the Rights of the Child states that:

"The arrest, detention or imprisonment of a child shall be in conformity with the law and shall be used only as a measure of last resort and for the shortest appropriate period of time". ${ }^{2}$

There is a marked gender difference, with boys greatly outnumbering girls (see table 1). Young black people are over-represented in the prison population; $20 \%$ of young people in prison are black as opposed to $2 \%$ of that age group in the population. ${ }^{3}$

The main offence groups were robbery, burglary, and violence against the person. ${ }^{1}$ Less than $25 \%$ of offences committed were violent. Boys are held in designated juvenile units, within young offender institutions, and girls are held in adult women's prisons. Ninety per cent more children are held in prison in England and Wales than 10 years ago. ${ }^{1}$ This increase may be attributed to both the increasing use of prison and the increasing length of sentences, despite the development of viable alternatives to custodial sentences. Sadly, reconviction rates for children leaving prison are very high; $88 \%$ of children who receive a custodial sentence reoffend within two years.

Boys aged 15 years and older and girls aged 17 years and older, may be held on remand. Children aged 12-17 may be held under sentence on a "Detention and Training Order", and children aged 10-17, if convicted of a grave offence, may be held under Section 90 or 91 of the Criminal Courts (Sentencing) Act. Once a child is given a custodial sentence, the Youth Justice Board decides whether the child will be placed in prison, in a secure training centre, or a local authority secure unit. ${ }^{4}$

Children in prison are a vulnerable and needy group. A high proportion (approximately 50\%) have been "in care", many have been excluded from school, few have academic qualifications, and almost a fifth admit to having suffered abuse of a violent, sexual, or emotional nature. ${ }^{5}$

Table 2 shows that there is a vastly greater proportion of children in prison in England and Wales than in any other state in the EU. ${ }^{5}$

There is no evidence that the level of youth offending is higher in England and Wales. ${ }^{5}$ Two possible reasons for the high proportion of children in prison in England and Wales are the young age of criminal responsibility (the UK age of 10 is one of the highest in Europe) and the attitude to sentencing in this country.

\section{HEALTH NEEDS OF CHILDREN IN PRISON}

There have been no studies investigating the health of children in prison. Assumptions have to be made from studies of the health of young offenders (aged under 21 years) and boys aged 12-17 years in secure units.

\section{Physical health}

In a survey of 590 young offenders (that is, those under 21 years), about a quarter of males, and a third of females, report suffering from a longstanding physical complaint. ${ }^{6}$ Common complaints were respiratory problems and musculoskeletal complaints.

Eighty per cent of the young offenders in this study were smokers and two thirds of male offenders and half of female offenders reported hazardous levels of alcohol consumption. Seventy per cent of the young offenders reported using at least one illegal drug in the same period, and 30\% had been using heroin. ${ }^{6}$

In Australia, Coffey and her colleagues found that young people who had served a custodial sentence had a significantly higher mortality rate than the general population of the State of Victoria. ${ }^{7}$

Young people incarcerated in prison, who may already be drug users, are at an increased risk of HIV, hepatitis B, hepatitis $\mathrm{C}$ infection, and tuberculosis. There are no recent studies of the prevalence of these infections among young offenders.

\section{Mental health}

Levels of mental illnesses are much higher in young people in prison than in the general population. ${ }^{5}$ The ONS survey found the prevalence rate for schizophrenia to be $6 \%$ for male young offenders and $9 \%$ for female young offenders. The rates for $16-19$ year olds living in private households is $0.2 \%{ }^{6}$

Boys in a secure unit run by the Department of Health, and managed by the local authority were found to have a high incidence of psychiatric disorders. ${ }^{8}$

In the past 10 years, 18 children have committed suicide in prison. Between April 2000 and November 2001 there were 554 incidents of self harm by children in prison. ${ }^{9}$ Ten per cent of young offenders have self harmed and $11 \%$ say they have contemplated suicide.

There are no studies of prevalence of attention deficit hyperactivity disorder or autistic spectrum disorders among young offenders in England and Wales.

\section{HEALTH PROMOTION}

Since 1997 there has been a Health Promoting Prisons Award. Could any prison be considered to be a health promoting environment, while children are not protected from violence, can be held in solitary confinement, and can be restrained using the same methods as those used for 
Table 1 Number of children in prison in England and Wales at end September 2002'

\begin{tabular}{|c|c|c|c|c|c|}
\hline \multirow[b]{2}{*}{ Age } & \multicolumn{2}{|c|}{ Sentenced } & \multicolumn{2}{|c|}{ Unsentenced } & \multirow[b]{2}{*}{ Total } \\
\hline & Boys & Girls & Boys & Girls & \\
\hline 15 & 250 & 5 & 44 & 0 & 299 \\
\hline 16 & 622 & 29 & 153 & 0 & 804 \\
\hline 17 & 1117 & 59 & 341 & 13 & 1530 \\
\hline Total & 1989 & 93 & 538 & 13 & 2633 \\
\hline
\end{tabular}

adults? A recent (July 2003) Judicial Review decision should put an end to the use of solitary confinement for children. ${ }^{10}$

\section{CHILD PROTECTION}

Although the government document, Working together to safeguard children, ${ }^{11}$ requires each prison holding young people under 18 years to establish its own child protection policy, there is no mention of child protection in the Prison Service Order, Regimes for prisoners under 18 years old. ${ }^{12}$ In February 2003, HM Inspector of Prisons described the conditions for girls held at Holloway Prison as "grossly inadequate" with little awareness of child protection procedures. ${ }^{13}$ Bullying, racism, physical, and sexual assault are endemic in some youth offending institutions. ${ }^{5}$

\section{HEALTH SERVICES FOR CHILDREN IN PRISON}

At present, the Prison Medical Service provides health services for those in prisons. In 1997, a study of health care in 19 prisons found that in many, the health care was of low quality, and some doctors were not adequately trained. ${ }^{14}$

The only mention of health care in the Prison Service Order, Regimes for prisoners under 18 years old, ${ }^{12}$ is the statement that it is mandatory for each young person to have an assessment of their health care needs on arrival, and that mental health services should be provided by a multidisciplinary team, skilled and experienced in adolescent health. There is no evidence that this is fulfilled and it may be that access to prison based or mainstream mental health services is patchy and inadequate.

\section{DISCUSSION}

There is an increasing number of children in prison in England and Wales. Although children do commit crimes, they also have education, health, and welfare needs. Prison may not be the best place to meet these needs. Alternative restorative justice programmes, which may include drug rehabilitation, meeting and apologising to the victim, and contracting to reparative actions, are available. ${ }^{15}$

Very little is known about health needs of children in prison. Studies of the health of young offenders suggest that child prisoners have significant physical and mental problems. A high quality, case-control study is required to accurately identify the health needs of children in prison.

A period in detention is currently a missed opportunity to detect, diagnose, and treat health problems in a population, which is often hard to engage in the NHS.

During the next five years, the commissioning and provision of health services to prisoners will become the responsibility of Primary Care Trusts (England) and Local Health Boards (Wales). It is important that the needs of these vulnerable and needy children should not be overlooked in this reorganisation. Planning for transfer of services will need to recognise the considerable shortfall in current funding and service provision.

Children in prison were not protected by the 1989 Children Act before 29 November 2002, when the High Court ruled
Table 2 Approximate under 18 prison population by country ${ }^{4}$

\begin{tabular}{|c|c|c|c|}
\hline Country & $\begin{array}{l}\text { Number in } \\
\text { custody (date) }\end{array}$ & $\begin{array}{l}\text { Custody per } 1000 \\
\text { total population }\end{array}$ & $\begin{array}{l}\text { Age of criminal } \\
\text { responsibility }\end{array}$ \\
\hline $\begin{array}{l}\text { England and } \\
\text { Wales }\end{array}$ & 2829 (31.10.01) & 0.24 & 10 years \\
\hline France & 809 (1.9.98) & 0.06 & 13 years \\
\hline Austria & 199 (31.8.99) & 0.12 & 14 years \\
\hline Portugal & $209(31.12 .99)$ & 0.12 & 16 years \\
\hline Belgium & $141(1.9 .98)$ & 0.09 & 18 years \\
\hline Netherlands & 79 (1.9.98) & 0.02 & 12 years \\
\hline Spain & 177 (1.9.98) & 0.02 & 16 years \\
\hline Denmark & 14 (12.9.98) & 0.01 & 15 years \\
\hline Finland & 7 (1.9.98) & 0.01 & 15 years \\
\hline
\end{tabular}

that the Act also applies to them. ${ }^{5}$ The government has recently published recommendations for promoting the health of children "Looked After" under the Children Act $1989 .{ }^{16}$ The challenge is to recognise and meet the needs of the vulnerable and needy children held in prison, identify remedial conditions, and ensure appropriate and effective health care planning (including health promotion) for all young people in custody.

We recommend that the Royal College of Paediatrics and Child Health should now actively promote the health care of children in prison, to, at least, the standard already recommended for Looked After Children. Services should be provided by professionals appropriately trained and skilled to work with children.

\section{Authors' affiliations}

J Gould, Paediatrics Department, Poole Hospital, UK

H Payne, Department of Child Health, University of Wales College of Medicine, Heath Park, Cardiff, UK

This work was part of the first author's submissions for a Master's Degree in Child Health at the University of Wales College of Medicine

Correspondence to: Dr J Gould, Paediatrics Department, Poole Hospital NHS Trust, Longfleet Road, Poole BH15 2JB, UK; john@doctors.org.uk

Accepted 19 September 2003

\section{REFERENCES}

1 Monthly Prison Population Brief. www.homeoffice.gov.uk/rds/prisons 1.html. Accessed 18 January 2003.

2 Children's Rights Development Unit. UK agenda for children 1994:201-6.

3 Hall D, Elliman D. Health for all children. Oxford: Oxford University Press, 2003.

4 Nacro. Children who commit grave crimes. London: Nacro, 2002.

5 Howard League. Children in prison. http://

webukonline.co.uk?howard.league/information/childrenprisons.html. Accessed 7 September 2002.

6 Lader D, Singleton N, Meltzer H. Psychiatric morbidity among young offenders in England and Wales. London: Office for National Statistics, 1997.

7 Coffey C, Veit F, Wolfe R, et al. Mortality in young offenders: retrospective cohort study. BMJ 2003;326:1064-6.

8 Kroll L, Rothwell J, Shah P, et al. Mental health needs of boys in secure care for serious or persisting offending: a prospective longitudinal study. Lancet 2002;359:1975-9.

9 Youth Justice Board. Speaking out. www.youth-justice-boare.gov.uk. Accessed 9 September 2003.

10 The Howard League for Penal Reform. Press information. http:// web.ukonline.co.uk/howard.league. Accessed 18 January 2003.

11 DOH. Working together to safeguard children. London: HMSO, 1999.

12 HM Prison Service. Regimes for prisoners under 18 years old. London: Home Office, 1997.

13 Howard League. Press release 18 February 2003. Howard League calls for girls to be removed from Holloway Prison. www.howardleague.org. Accessed September 2003.

14 Reed J, Lynne M. The quality of health care in prisons. BMJ 1997:315:1420-4.

15 Youth Justice and Criminal Evidence Act. www.homeoffice.gov.uk/docs/ yopanel $1 \mathrm{html}$. Accessed September 2003.

16 DOH. Promoting the health of looked after children. London: HMSO, 2002. 